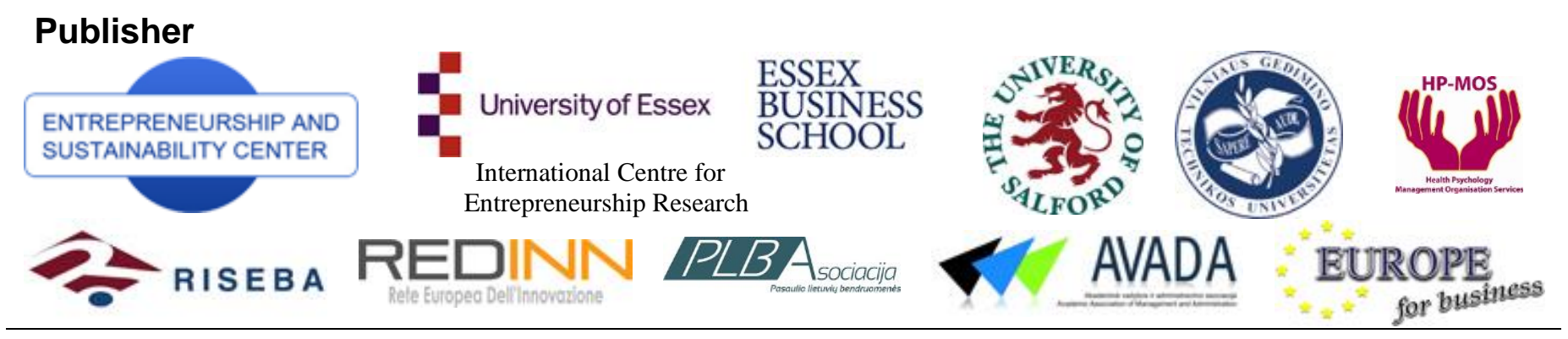

ENTREPRENEURSHIP AND SUSTAINABILITY ISSUES

ISSN 2345-0282 (online) http://jssidoi.org/jesi/aims-and-scope-of-research/

\title{
EFFECTS OF CONSUMER BEHAVIOUR ON INNOVATIONS IN FAST FOOD INDUSTRY
}

\author{
Mindaugas Laužikas ${ }^{1}$ Hailee Tindale², Lukas Tranavičius ${ }^{3}$, Emilis Kičiatovas $^{4}$ \\ ${ }^{1,2}$ ISC Paris Business School (Institut supérieur du commerce de Paris) \\ Sis 22, Boulevard du Fort de Vaux 75848 PARIS Cedex 17 \\ E-mails: $\frac{1 \text { mlauzikas@iscparis.com; }{ }^{2} \text { htindale@iscparis.com; }{ }^{3} \text { lukas.tranavicius@gmail.com; }}{\text { emilis.kiciatovas@gmail.com }}$
}

\begin{abstract}
The purpose of this study is to examine effects of consumer behaviour on innovation commercialization among fast food restaurants via the analysis of restaurant selection criteria in the Lithuanian fast food market. In today's global economic competitive environment where innovation is becoming more important, companies need to successfully manage innovations in order to ensure their competitive advantage, exploit new markets and attract customers. There is extensive research in the area of innovation (for instance, Schumpeter, 1934; Drucker, 2002; Lundvall, 2004; Freeman, 1982; Alam and Perry, 2002; Berghman, 2008; Ottenbacher, 2007, 2008 and etc.); however, the literature on the impact of consumer behaviour on commercialization of innovation is not well-established. The paper is innovative and relevant due to the selected fast food industry for analysis. It addresses the question: how does consumer behaviour contribute to innovation processes in the fast food industry and what are the ways to optimize the innovation performance, based on consumer needs? Fast food could be considered as an innovation itself. Nowadays it is not enough to just provide a fast food. Companies need to innovate in order to attract new customers - there is a new trend of healthy fast food, where requirements for fast food companies are very high. The present paper overviews and compares the academic literature on innovation, various classifications of innovation types and innovation process. It also presents the specific trends and issues of the EU system of innovation, choosing the Lithuanian case due to its sensitivity to transformation and rapid improvements, and only then it evolves into a quantitative survey-based study on fast food; restaurant selection criteria.
\end{abstract}

Keywords: innovation, commercialization, fast food industry, consumer behavior, restaurant selection criteria.

Reference to this paper should be made as follows: Laužikas, M.; Tindale. H.; Tranavičius, L.; Kičiatovas, E. 2015. Effects of consumer behaviour on innovations in fast food industry, Entrepreneurship and Sustainability Issues 3(1): 85-103.

DOI: http://dx.doi.org/10.9770/jesi.2015.3.1(8)

JEL classification: M130 New Firms; Startups

\section{Introduction}

The academic literature outlines many definitions of innovation, but in general innovation is an unavoidable process of applying new products, ideas or business processes to companies' activities in order to create greater value in a final offering and gain competitive advantage (Stock et al. 2002). To analyse innovation in-depth it is necessary to overview studies of different well-known scholars, although there is no universally shared conceptualization of innovation (Amara, Landry 2005).

According to Staškevičius (2004), the meaning of word 'innovation' is related to the 15th century French word inovacyion, which means an item update or giving a new shape to an object. Thus, the most of the time it is 
associated with words 'new' or 'change'. Schumpeter (1934), the first scholar who defined innovation, states that innovation is the creation of new combinations. Schumpeter relates definition of innovation to an introduction of a new or new-quality good (yet unfamiliar for customers); a new production method related with scientific discoveries; the opening of a new market, which has not been entered by a particular branch of manufacturing; the introduction of new supplies and raw materials and finally - new creation of organizational structure, for example, creation or braking up of a monopoly position (Schumpeter 1934). This well-known theoretician also argued that everybody who expected to gain a competitive advantage and made a profit faced innovation. In his book 'Capitalism, Socialism and Democracy' (1942) Schumpeter created a term 'creative destruction', which is a 'process of industrial mutation that incessantly revolutionizes the economic structure from within, incessantly destroying the old one, incessantly creating a new one. It is a center of economic change, driven by innovation and the essence of capitalism'.

Another important Schumpeter's discovery is the dividing of the innovation process into four dimensions: invention, innovation, diffusion and imitation. Here, he states that only the invention or discovery itself do not have a great impact on economy, so diffusion and imitation stages are more important, because here imitators realize the potential of innovation and start investing money - innovation is applied beyond its origin. Schumpeter established that innovation did not require any special or new knowledge; instead he noted that innovation would appear when existing knowledge had not been utilized in a specific industry. According to him - innovation is the act of will, leadership and risk taking activities rather than a result of human intelligence 'The pure new idea is not adequate by itself to lead to implementation. It must be taken up by a strong character (entrepreneur) and implemented through his influence' (Schumpeter 1912, p.543).

Another author B. Ludvall expanded this theory and stated that innovation had direct and indirect costs. Direct costs include development, implementation and use of something new directly involved in the innovation process, and indirect costs involve people and organizations that have little influence on the innovation process (employees loosing value of their qualification, durable goods loose value when new ones come to the market etc.). In his book 'Innovation, Growth and Social Cohesion: The Danish model' (B. Lundvall, 2004), he further analyzed the knowledge-based economy and explained that sectors which use knowledge the most - for example R\&D or skilled labor - are the ones who grow most rapidly and therefore, innovate the most. He adds that innovation takes place when a firm develops a new production process, a new product or a new service and introduces it in the market. Again, both Schumpeter and Lundvall state that innovation stage is not the most important one, because all innovations require adaptation in the market until it becomes fit in the context. Dissemination stage is where the innovation is improved, made cheaper and more usable; this is why it is so important (Lundvall 2004).

Lundvall also emphasizes the importance of scientific research, which he links with knowledge-universities that are crucial for technical progress to be achieved. The combination of theoretical and practical knowledge is necessary. He also defined the innovation system, which is a result of a social process involving interplay between many individuals and organizations over a longer period of time in which cumulative learning processes take place. It can be either between basic research, applied research, universities or industry knowledge production, which explains that innovation system can take place in all sectors of a private economy, between private firms, in knowledge institutions and organizations. Firms, in order to survive and innovate without technology and research, innovate in organizational and marketing techniques, which approve Schumpeter's idea that innovations are essential for economic growth.

Another influential innovation and management philosopher Peter Drucker, in his book 'Innovation and Entrepreneurship' (1986) defined innovation as a specific instrument of entrepreneurship with the associated resources and a new capacity to create wealth. In a similar way like Lundvall the author states that innovation does not necessarily have to be technical - it is mostly related with knowledge management, which enables people, with different skills working together within an organization, to explore opportunities (Drucker 2002). This is why innovation is an economic or social rather than a technical term. Furthermore, according to Drucker, innovation is a systematic phenomenon and consists of purposeful and organized search for changes and 
opportunities, which are main sources of innovation. Being successful in innovation is being successful in monitoring seven sources of innovative opportunity:

1. The unexpected success, failure or outside event that can possibly lead to an innovative opportunity, because most companies disregard and dismiss them.

2. Incongruities or conflicts between opposing functions, requirements or values, for example an incongruity between an economic reality of an industry and the assumptions about it, or the ones in production distribution or consumer behavior.

3. Process needs, which often evolve from a specific need to achieve a result faster and more efficient.

4. Industry and market structure - Industry markets and market structure may offer opportunities for new types of services. Outsourcing of activities such as maintenance of the IT infrastructure is a good example.

5. Demographics - population, age distribution, education, occupations, geographic location etc. changes.

6. Changes in perception - changes of the meaning of facts and thoughts about them.

7. New knowledge - innovations based on scientific, technical or social knowledge are the ones, which are the most successful and most frequent ones.

In general Drucker claimed that innovations have to be simple and concentrated. They require knowledge and creativity, and, most importantly, they have an effect in economy and society - so it is market driven (Drucker 1986). According to Drucker, innovators are people who minimize risks and systematically analyse and exploit the sources of opportunity.

Despite the change in the economic landscape, Schumpeter's, Lundvall's and Drucker's ideas remain the main starting point and the base for any other theories. Many other thinkers have tried to define the term innovation. They have all drawn a similar definition, but every one of them added their own thoughts, models and types. Different innovation definitions reveal new attributes, meanings and add new information which has not yet been discovered. Trott (2005) states that innovation is the epicenter of many companies. Going back to 1982, Christopher Freeman revealed that not to innovate was to die - this explains that people realized the importance of innovation. Table 1 represents the summary of innovation definitions that are important to outline in order to be successful in analyzing innovations.

Table 1. Definitions of innovation

\begin{tabular}{|c|c|}
\hline Authors & Definitions of innovation \\
\hline Paul Trott (2005) & $\begin{array}{c}\text { Innovation }=\text { theoretical assumption }+ \text { technical invention }+ \\
\text { commercial exploitation }\end{array}$ \\
\hline Tidd, Bessant, Pavitt (1997). & $\begin{array}{c}\text { Embodiment, combination, or synthesis of knowledge which is } \\
\text { original, relevant, and gives added-value to a product, process or } \\
\text { service }\end{array}$ \\
\hline Crossan and Apaydin (2010) & $\begin{array}{l}\text { Introduction of new products and successful commercialization of } \\
\text { new combinations, based on the application of new materials and } \\
\text { components, the introduction of new processes, the opening of } \\
\text { new markets or the introduction of new organizational forms }\end{array}$ \\
\hline The European Commission Green Paper (1995) & $\begin{array}{l}\text { Successful production, assimilation and exploitation of novelty in } \\
\text { the economic and social spheres }\end{array}$ \\
\hline Oslo Manual, OECD (1997). & $\begin{array}{l}\text { Providing new or improving existing ones products by } \\
\text { successfully commercializing new technologies, ideas, methods }\end{array}$ \\
\hline P. Kulviecas (1991). & $\begin{array}{l}\text { Complex creation, development, global spread and effective usage } \\
\text { of novelties in various areas of human activities. It is a process } \\
\text { which includes the research, preparation, management and } \\
\text { functionality in order to achieve a specific result }\end{array}$ \\
\hline Jakubavicius, Strazdas, Gečas (2003) & $\begin{array}{c}\text { Complex and dynamic phenomena which involves many } \\
\text { stakeholders, such as institutions, businesses, suppliers, clients, } \\
\text { consultancy agencies, economic development agencies, business } \\
\text { associations, educational institutions, financial institutions etc., so } \\
\text { it is crucial to see innovations as advancement process, where } \\
\text { companies and partners interact }\end{array}$ \\
\hline
\end{tabular}

Source:Prepared by authors, based on Trott (2005); Crossan and Apaydin (2010); European Commision (1997); Jakūbavičius et al. (2003). 


\section{Classifications of innovation}

Innovation literature classifies innovations according to many frameworks, developed by different researchers. Firstly, they can be classified, based on their models. There were several different models of innovation distinguished by different scholars throughout the $20^{\text {th }}$ century (Table 2 ).

Table 2. Models of innovation

\begin{tabular}{|c|c|c|}
\hline Year & Model & Explanation \\
\hline $1950 / 60 \mathrm{~s}$ & Technology push & $\begin{array}{c}\text { Simple linear model, with emphasis on the R\&D. Unexpected discoveries, with the help } \\
\text { of technologies, are transformed into product ideas and pushed with marketing and sales } \\
\text { techniques to the market. Here, market place has a reactive role. }\end{array}$ \\
\hline $1970 \mathrm{~s}$ & Market pull & $\begin{array}{c}\text { Simple linear model, with emphasis on marketing. Innovations arise from close } \\
\text { interaction with customers. Consumer needs-driven industry directs R\&D. }\end{array}$ \\
\hline $1980 \mathrm{~s}$ & Coupling model & $\begin{array}{c}\text { Model emphasizes that innovation is a result of simultaneous coupling of the knowledge } \\
\text { within manufacturing R\&D and marketing. }\end{array}$ \\
\hline $1980 / 1990 \mathrm{~s}$ & Interactive model & $\begin{array}{c}\text { It links push and pull models together and emphasizes the interaction between the } \\
\text { marketplace, science base and organizational capabilities. Innovations can arise from } \\
\text { various sources based on knowledge transfers, and organizations which are able to } \\
\text { manage this process will be efficient in innovation. }\end{array}$ \\
\hline $2000 \mathrm{~s}$ & Network model & $\begin{array}{c}\text { The center of this model is organizational functions of R\&D, engineering, } \\
\text { manufacturing and marketing. The flow of communication between these functions is } \\
\text { free, and linkages occur between all functions. In this way innovation can occur in any } \\
\text { stage. }\end{array}$ \\
\hline
\end{tabular}

Source: Prepared by authors, based on Trott (2005)

Since the word 'innovation' can be related to different kinds of 'newness' regarding different products, production methods, technologies, markets, and organizational processes, the innovation theory developers have distinguished different types of innovation.

For the first time, different types of innovation were introduced by Schumpeter in 1942 that were called 'discontinuities'. The two types of innovation he identified were: competency-destroying and competenceenhancing discontinuities. The first one referred to a disruptive innovation that requires replacing existing technology, while a competence-enhancing innovation is developed on existing know-how. These two types presented by Schumpeter gave a strong background for further research regarding different types of innovation. Many experts now agree on existing four types: disruptive, discontinuous, radical and incremental innovations. Christensen (1997), a researcher at Harvard Business School, explained that disruptive innovation comes in a form of less functional products or services at a much lower price, targeting a significant number of customers who are satisfied with lower performance and functionality of a new technology. Gradually, a new product is being improved and finally it completely replaces the old version. Secondly, discontinuous innovations require customers to change their behavior and adapt to the new technology (Walsh, Kirchhoff 2000). Although these two types of innovation are similar, because in both cases a new technology changes the old one, still, controversy is present. Linton and Walsh (2002) add that disruptive technologies are discontinuous, but discontinuous technologies are not necessarily disruptive. It means that discontinuous innovations become disruptive only when existing technology is not prepared for a new rival and does not have enough experience to survive (Philips, Nokes 2003). In addition, if companies with old technology have enough skills and experience, it is more likely that they will survive (Tripsas 1997; Rothaermel 2002).

The other two types of innovation are incremental and radical which, according to Tushman and O'Reilly (2004), are types that companies should focus on. The first one is incremental or continuous innovation which defines small changes and adjustments to existing products, services or processes, and requires companies to focus on development and improvement of existing production line. The second type is radical or discontinuous innovation that refers to the introduction of an entirely new kind of product in the market, and requires architectural and creativity skills of an organization. For a better view, Leifer et al. (2000) explain that innovation, in order to be radical, has to be one or more of the following: 
- an entirely new set of performance features,

- improvements in known performance features,

- improvements in known performance features of five times or greater,

- significant (30\% or greater) reduction in cost.

In order to expand the perception about incremental and radical innovations, Olson et al. (1995) suggest four categories which define innovation more specifically. These categories are: new-to-the-world products, line extensions, me-too products and product modifications. The first category refers to products and services which are new to the market and company which develops it. Line extensions are complementary products or additional parts that are also new to the market, but not for a company. Me-too products are described as imitated products that are known to the marketplace but new to a company. The last category is product modification which defines existing products that are new neither to the market nor to a company.

Furthermore, regarding Schumpeter's theory, more recent researchers continue to develop classification of innovation and suggest another four types which are architectural innovation, market niche innovation, regular innovation and revolutionary innovation (Abernathy, Clark 1985; Tidd 1993). The first type is architectural innovation which is defined as a basic configuration of process that will influence further development of product or service. The second one, market niche innovation, refers to new market opportunities using existing technology. Regular innovation, the third, is a change built on the technical and production competence and applied to existing markets in order to strengthen the product position. The last type is revolutionary innovation that is referred to disruptive technologies that replaces previous versions. These categories reflect previously described ones, only with minor variations in order to specify description and improve understanding of innovation types. It is possible to compare the first three categories with Schumpeter's competence-enhancing discontinuity and the forth with competency-destroying discontinuity.

Some researchers believe that it is important to understand varying degrees of innovativeness, since different types of innovation need different conditions to be implemented successfully. Heany (1983) suggests six degrees of innovations according to four conditions he raises (see Table 3). They are style change, product-line extension, product improvement, new product, start-up business, major innovation. So according to Heany (1983), in order to match innovation with appropriate degree of innovativeness it is necessary to answer questions, such as: whether market for product is established or not, whether business already is serving the market, do customers know functions and features of a product, and what is the design effort for a product or process (Table 3).

Table 3. Degrees of Innovation

\begin{tabular}{|c|c|c|c|c|c|}
\hline \multicolumn{6}{|c|}{ Degrees of Innovation } \\
\hline \multirow{2}{*}{$\begin{array}{c}\text { Is the market for } \\
\text { product } \\
\text { established? }\end{array}$} & \multirow{2}{*}{$\begin{array}{l}\text { Is the business } \\
\text { already serving the } \\
\text { market? }\end{array}$} & \multirow{2}{*}{$\begin{array}{c}\text { Do customers } \\
\text { know functions and } \\
\text { features? }\end{array}$} & \multicolumn{2}{|c|}{ What is the design effort? } & \multirow[t]{2}{*}{ Then innovation is a: } \\
\hline & & & Product & Process & \\
\hline Yes & Yes & Yes & Minor & Nil & Style change \\
\hline Yes & Yes & Yes & Minor & Minor & Product-line extension \\
\hline Yes & Yes & Yes & Significant & Minor & Product improvement \\
\hline Yes & Yes & Yes & Major & Major & New product \\
\hline Yes & No & Yes & Major & Major & Start-up business \\
\hline No & No & No & Major & Major & Major innovation \\
\hline
\end{tabular}

Source: Von Stamm (2008). Managing innovation, design and creativity. 2nd ed. Glasgow: Bell \& Bain.

Moreover, many researchers agree that innovation can come up not only as a product or service concept, but also can be implemented in such areas as process or business model (Tidd 2001) or paradigm innovation (Bessant, Tidd 2007), position innovation (Francis, Bessant 2005) which is related to the context in which a product or service are introduced. Since there are different areas where innovation can be introduced and previously 
discussed types of innovation - discontinuous, radical and incremental - the innovation-scape can be (Tidd et al., 2001) presented in the Table below.

Table 4. Examples of each type within each category

\begin{tabular}{|c|c|c|c|c|}
\hline Discontinuous & Cars instead of horses & Internet banking & $\begin{array}{l}\text { Pilkington's floating } \\
\text { glass }\end{array}$ & Internet \\
\hline Radical & $\begin{array}{l}\text { Hydrogen } \\
\text { powered cars }\end{array}$ & $\begin{array}{l}\text { A new kind of } \\
\text { mortgage }\end{array}$ & $\begin{array}{l}\text { Gas-filled thermo glass } \\
\text { panes }\end{array}$ & $\begin{array}{l}\text { Online sales \& } \\
\text { distribution of } \\
\text { computers }\end{array}$ \\
\hline \multirow[t]{2}{*}{ Incremental } & New car model & $\begin{array}{l}\text { Different mortgage } \\
\text { feature }\end{array}$ & Different colored glass & $\begin{array}{l}\text { Selling in business } \\
\text { parks instead of town } \\
\text { centers }\end{array}$ \\
\hline & Product & Service & Process & Business Model \\
\hline
\end{tabular}

Source: Von Stamm (2008). Managing innovation, design and creativity. 2nd ed. Glasgow: Bell \& Bain.

Furthermore, Paul Trott in his book 'Innovation management and new product development' also distinguishes 7 types of innovation types, which are presented in the Figure 1.

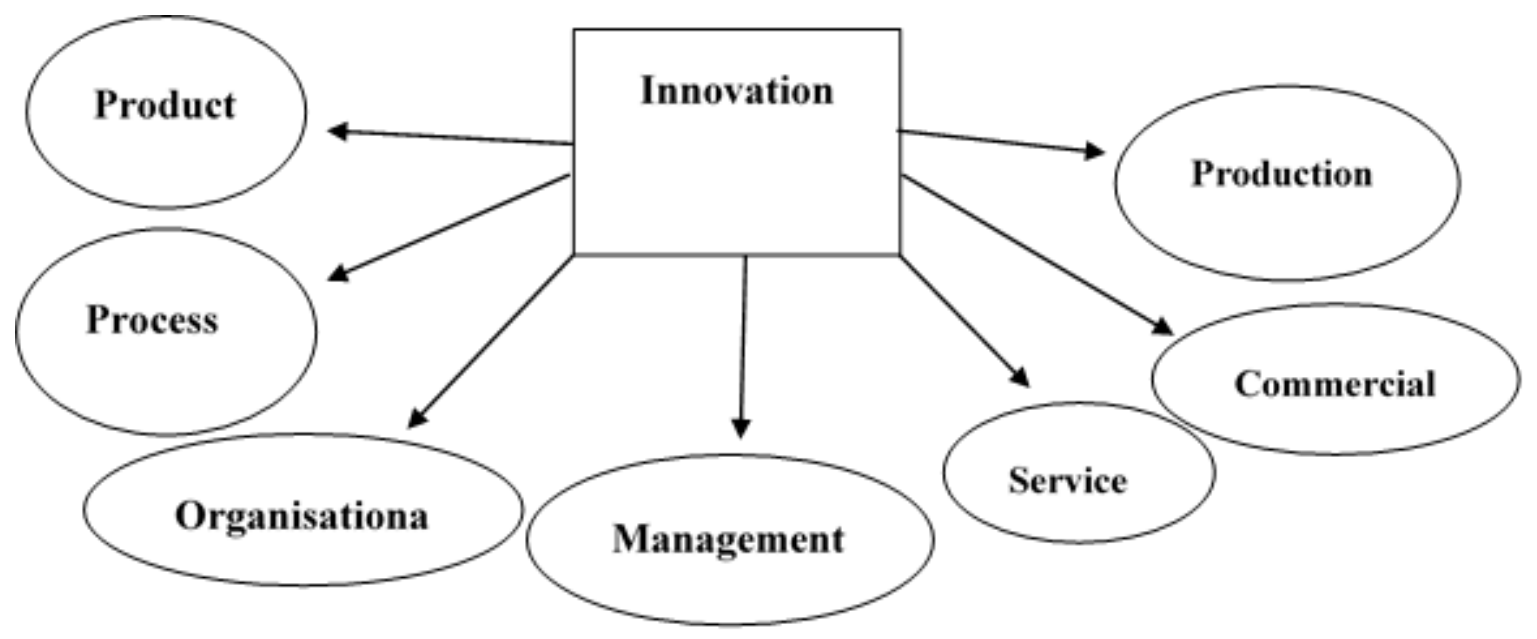

Fig 1. Trott's types of innovations

Source: Trott (2005). Innovation Management and New Product Development. 3rd ed. University of Portsmouth, Great Britain.

Clarysse et al. (1998) and Lundvall's (1992) classifications are more general and identify four domains of innovation, presented in the Figure 2. 


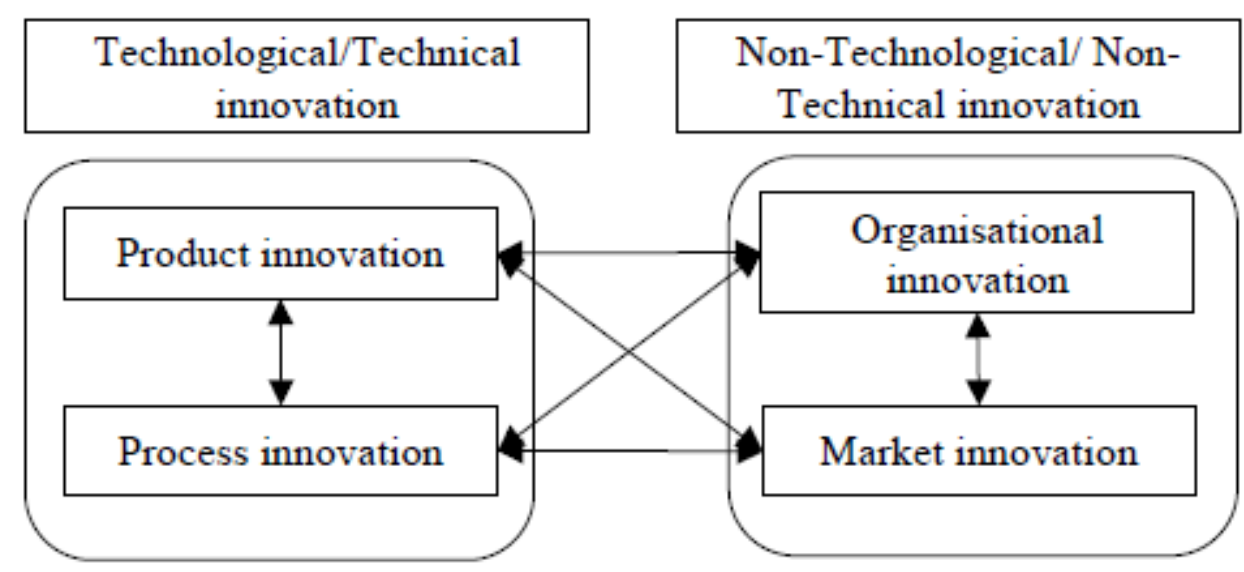

Fig 2. Four domains of innovation

Source: Bigliardi and Dormio (2009). An empirical investigation of innovation determinants in food machinery enterprises. European Journal of Innovation Management. Vol. 12 No. 2, pp. 223-242.

Generally, product innovation is a good, service or idea that is perceived as new; process innovation is the adaptation of existing production lines or an installation of a new infrastructure or technology, which allows the creation of new products; organizational innovation are changes in marketing, purchases, sales, administration, management, staff policies, while market innovation is the exploitation of new markets or the penetration of new market segments within existing markets. Figure 1 perfectly explains Lundvall's (1992), definition where innovation can be considered an ongoing process of leaving, searching and exploring which results in new products, new processes, new forms of organization and new markets.

\section{The Lithuanian innovation framework}

In order to be more extensive in analyzing Lithuanian innovation peculiarities the need to overview insights of Lithuanian authors emerges. In their book on innovation management Melnikas, Jakubavicius and Strazdas (2000) define innovation as a functional and advanced novelty, oriented to changing the old to the new. Innovation can be seen as an idea, activity or a new tangible object, which is new to people or organization. These authors developed a framework for innovation classification, which is highly applicable and is not inferior than any other model developed by well-known international scholars:

Table 5. Lithuanian innovation classification framework

\begin{tabular}{|c|c|c|}
\hline $\begin{array}{l}\text { Classification } \\
\text { according: }\end{array}$ & Patterns: & Explanation: \\
\hline \multirow[t]{4}{*}{ Content } & Product & $\begin{array}{l}\text { The creation, production and usage of new final products (means of } \\
\text { production, consumable goods, tangible and intellectual property) }\end{array}$ \\
\hline & Technological & The creation and implementation of new technologies \\
\hline & Social & $\begin{array}{c}\text { The creation and implementation of new economic, managerial, organizational } \\
\text { and other structures in various activities }\end{array}$ \\
\hline & Complex & Synthesis of product, technological and social innovations \\
\hline \multirow{5}{*}{$\begin{array}{c}\text { Level of } \\
\text { implementation }\end{array}$} & Human & Implemented by an individual himself \\
\hline & $\begin{array}{c}\text { Companies, organizations and } \\
\text { institutions }\end{array}$ & Implemented on a company basis \\
\hline & Society or state & Implemented by a society or a nation \\
\hline & Ecosystem & Changes the surrounding environment \\
\hline & The world & Innovation that changes the world \\
\hline \multirow[t]{2}{*}{ Extent of innovation } & Single & Implemented on time only \\
\hline & Multiple & Can be implemented more times \\
\hline $\begin{array}{l}\text { Novelty of } \\
\text { innovation }\end{array}$ & Radical & $\begin{array}{l}\text { A completely new and unseen innovation, which completely changes society } \\
\text { activities. }\end{array}$ \\
\hline
\end{tabular}




\begin{tabular}{|c|c|c|}
\hline & Incremental & $\begin{array}{l}\text { Improvement and supplementation with existing measures, according to the } \\
\text { needs of society }\end{array}$ \\
\hline \multirow{2}{*}{$\begin{array}{l}\text { Organizational } \\
\text { characteristics }\end{array}$} & Internal & Innovation development and implementation is held inside the organization \\
\hline & External & $\begin{array}{l}\text { The dissemination of innovation process functions among different } \\
\text { organizations }\end{array}$ \\
\hline \multirow[t]{2}{*}{ Nature of innovation } & Quantitative & The increase of productivity or volume of production, \\
\hline & Qualitative & The increase of quality in production and management \\
\hline \multirow[t]{5}{*}{ Final result } & Fundamental & The final result of innovation is an academic theory in written from \\
\hline & Experimental & $\begin{array}{l}\text { The final result of innovation is an example of a product, created according to } \\
\text { an academic theory }\end{array}$ \\
\hline & Basic & $\begin{array}{l}\text { The final result is an example of a product which is used in mass production } \\
\text { or an organization }\end{array}$ \\
\hline & Diffusional & $\begin{array}{l}\text { The final result is the application of a product already produced for mass } \\
\text { production in a new specific market }\end{array}$ \\
\hline & Conditional & $\begin{array}{l}\text { the final result is modernization or improvement of already existing product, } \\
\text { which is similar but has newer technological characteristics }\end{array}$ \\
\hline
\end{tabular}

Source: Prepared by authors, based on Melnikas, Jakūbavičius and Strazdas (2000). Inovacijų vadyba. Technika, Vilnius.

\section{Innovation policy in European Union and Lithuania}

The EU strategy for economic growth: Europe 2020 emphasizes the importance of innovation in order to ensure a stable growth of the EU economy. Research and development and innovation should help Europe to stay competitive in the global knowledge economy. One of the key issues is to ensure access to finances for research and innovation, which will foster innovative ideas and turn them into new products or services that create growth and employment opportunities. A lot of new initiatives have been introduced to foster the innovation policy in the EU.

The European Commission has developed the Innovation Union flagship initiative 'Innovation Union', which is expected to improve innovation conditions in the European Union. José Manuel Barroso emphasized the importance of speeding up industrial innovations by ensuring the timely deployment and commercialization of key technologies to help European firms benefit from globalization and have the access to new markets through new trade agreements.

'Open Innovation 2.0', where the aim is to create an action plan, is to help achieve a sustainable economy and society, encourage innovation between the state and business sectors, through the development of public-private partnerships. Furthermore, in order to facilitate co-operation and knowledge sharing between national and regional stakeholders, European Innovation Partnerships are to be set up. This will create a 'knowledge triangle' of research, education and innovation, which will create interaction between these three sides. The open innovation approach fits well efforts to bring Europe back to a sustained economic activity and prosperity. Like Europe 2020, open innovation thrives on the involvement of all stakeholders - in government, industry, academia and citizens. This is why it is focused on forward public-private partnerships for innovation and European innovation partnerships on such issues as healthy ageing and raw materials.

The European Union outlines specific activities and policy priorities to boost innovation processes: the addedvalue manufacturing; food4future - sustainable supply chain from resources to consumers; innovation for healthy living and active ageing; raw materials - sustainable exploration, extraction, processing, recycling and substitution; smart secure societies, the urban mobility. In addition, according to the Standard Euro barometer 80 (2014), innovation is perceived as important in all member states: in Spain $(79 \%,+8)$, in Portugal $(72 \%,+10)$, Finland $(68 \%,+9)$ and the Netherlands $(69 \%,+9)$, Slovenia $(62 \%,-8)$.

In order to measure the innovation performance in EU member states the "Innovation Union" initiative is using Innovation Union Scoreboard. It distinguishes three main types of indicators to measure the performance Enablers (human resources, finance and support, open, excellent and attractive research systems), Firm activities (firm investments, linkages \& entrepreneurship, intellectual assets) and Outputs (innovators, economic effects), 
which fall into 8 innovation dimensions, and in total of 25 indicators. The main indicator to measure a country's innovation performance is the R\&D intensity (the R\&D expenditure as a percentage of GDP), which shows the extent of research and innovation activities in a specific country in terms of resource input. Currently, the target for 2020 policy is set for R\&D intensity of 3\% (R\&D expenditure as a percentage of GDP). Figure 3 represents a summary of the Innovation Index 2014 and distinguishes four groups of member States, according to their performance:

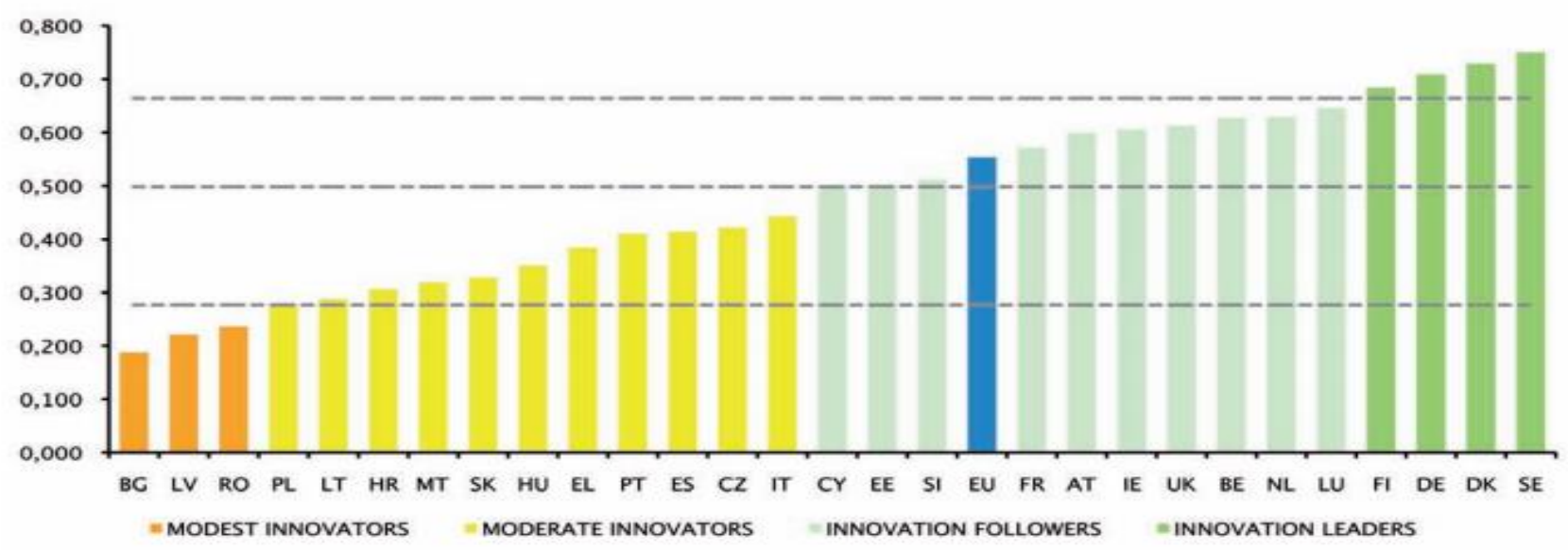

Fig. 3. Innovation performance in the European Union

Source: Hollanders and Sadki (2014). Innovation Union Scoreboard. Maastricht Economic and Social Research Institute on Innovation and Technology, Netherlands.

Innovation leaders are countries where the innovation performance is above the EU average, i.e. more than $20 \%$ above the EU average. Such countries as Denmark, Finland, Germany and Sweden belong to this category. These countries retained leading positions, compared to last year's edition of the Innovation Union Scoreboard. Innovation followers - innovation performance is close to the EU average level, i.e. less than $20 \%$ above, or more than $90 \%$ of the EU average. Austria, Belgium, Cyprus, France, Ireland, Luxembourg, Netherlands, Slovenia and the UK belong to this group. Moderate innovators are the countries with the innovation performance below the EU average at relative performance rates between $50 \%$ and $90 \%$ of the EU average. Such countries as Croatia, Czech Republic, Greece, Hungary, Italy, Lithuania, Malta, Poland, Portugal, Slovakia and Spain belong to this group. Modest innovators - with the innovation performance level well below the EU average, i.e. less than $50 \%$ of the EU average. Bulgaria, Latvia and Romania belong to this category.

According to this research, Lithuania is a moderate innovator, which is below the EU average; however, within the European Union Innovation Scoreboard 2013, Lithuania was among modest innovators and improved its innovation performance to a moderate innovator's level. This result is achieved through the Innovation Development Programme 2014-2020, a strategic document, which sets guidelines, goals and objectives for the innovation policy in Lithuania. The main goal of this programme is to enhance the competitiveness of the Lithuanian economy by creating an efficient system of innovation stimulating the innovativeness of economy. The objectives are as follows:

- to develop an innovative society by developing new knowledge and its application;

- to enhance business innovation potential;

- to promote the creation of value networking, development and internationalization;

- to increase efficiency of innovation policy-making and implementation and to promote innovation in the public sector. 
The activity, formation and implementation of the Innovation Development Programme 2014-2020 is monitored by the Ministry of Economy and Ministry of Education and Science. It ensures that all objectives are met and best results achieved. Lithuania is still less innovative than most European countries, but there is a positive trend of catching up visible, which makes the choice of Lithuania and its fast food industry as an object of the present research pertinent and value-adding.

\section{Methodology}

The study is centred on quantitative analysis, focused on finding out what innovations are the most attractive to Lithuanian customers while selecting a fast food restaurant, and what companies should do in order to increase profit. The main objectives of this study were to analyze whether innovations, in specific restaurant selection criteria groups, are important to customers; understand customer preferences and perceptions of the role of fast food innovation among different age, gender and income groups. First of all, the previously accomplished research on selection criteria of fast food restaurants were overviewed and summarized (see Table 6).

Table 6. Overview of research on selection criteria

\begin{tabular}{|c|c|c|c|}
\hline Name, Author, Year & Methodology & The Goal & Results \\
\hline $\begin{array}{l}\text { Consumer evaluations } \\
\text { of fast food services: a } \\
\text { cross-national } \\
\text { comparison. Moonkyu } \\
\text { Lee, Francis M. Ulgado } \\
\text { (1997). }\end{array}$ & $\begin{array}{l}\text { The questionnaire was used as the } \\
\text { main tool for the research. It consisted } \\
\text { of three parts: measurement of } \\
\text { expectations about provided services, } \\
\text { measurement of perceptions of those } \\
\text { services and demographic } \\
\text { characteristics. }\end{array}$ & $\begin{array}{l}\text { The goal of this research } \\
\text { was to find out if there were } \\
\text { significant differences in } \\
\text { the US and South Korean } \\
\text { consumers' perceptions of a } \\
\text { fast-food restaurant service. }\end{array}$ & $\begin{array}{l}\text { The results indicated that } \\
\text { significant differences may exist } \\
\text { between the US and South } \\
\text { Korean patrons in terms of their } \\
\text { expectations and perceptions of } \\
\text { fast-food restaurant services, } \\
\text { especially McDonald's. }\end{array}$ \\
\hline $\begin{array}{c}\text { Restaurant marketing: } \\
\text { selection and } \\
\text { segmentation in Hong } \\
\text { Kong. Jakša Jack Kivela } \\
\text { (1997) }\end{array}$ & $\begin{array}{l}\text { A pilot questionnaire was used } \\
\text { containing open-ended questions that } \\
\text { were distributed to } 60 \text { people. }\end{array}$ & $\begin{array}{l}\text { The goal was to determine } \\
\text { customers' perceptions of } \\
\text { restaurants and to assess the } \\
\text { way they choose different } \\
\text { type of restaurants, and } \\
\text { whether their decisions } \\
\text { support the perception of } \\
\text { restaurants. }\end{array}$ & $\begin{array}{l}\text { Results showed that consumer } \\
\text { perceptions and preferences of } \\
\text { choice variables vary } \\
\text { considerably by restaurant type. } \\
\text { The most significant selection } \\
\text { criteria of restaurant type was } \\
\text { dining occasion. }\end{array}$ \\
\hline $\begin{array}{c}\text { Consumer perception } \\
\text { about fast food in India: } \\
\text { an exploratory study. } \\
\text { Anita Goyal and N.P. } \\
\text { Singh (2007) }\end{array}$ & $\begin{array}{l}\text { The research used multivariate } \\
\text { statistical tools to estimate importance } \\
\text { of selection criteria. The questionnaire } \\
\text { was used containing demographic and } \\
\text { behavioral questions, factors affecting } \\
\text { selection, comparisons between fast } \\
\text { food restaurants, media for source of } \\
\text { information for fast food restaurants } \\
\text { and provision of information sharing. }\end{array}$ & $\begin{array}{l}\text { The goal was to estimate } \\
\text { importance of various } \\
\text { factors affecting the choice } \\
\text { of fast food restaurants by } \\
\text { Indian young consumers. }\end{array}$ & $\begin{array}{l}\text { The results identified that young } \\
\text { consumers are influenced by } \\
\text { variables like environment at } \\
\text { home, educational environment, } \\
\text { availability and accessibility to } \\
\text { fast food providers, and social } \\
\text { environment in their } \\
\text { surroundings. }\end{array}$ \\
\hline $\begin{array}{l}\text { Consumer behaviour in } \\
\text { the market of catering } \\
\text { services in selected } \\
\text { countries of Central- } \\
\text { Eastern Europe. Anna } \\
\text { Dabrowska (2011) }\end{array}$ & $\begin{array}{l}\text { The consumer study of an Omnibus } \\
\text { type was carried out by GfK Research } \\
\text { Company. The qualitative and } \\
\text { quantitative analysis were performed. }\end{array}$ & $\begin{array}{l}\text { The purpose of this paper is } \\
\text { to present consumer } \\
\text { behaviour in the market of } \\
\text { catering services in } \\
\text { Lithuania, Latvia, Poland } \\
\text { and Ukraine }\end{array}$ & $\begin{array}{l}\text { Research identified specific } \\
\text { consumers' selection criteria of } \\
\text { catering service, which were: } \\
\text { price, quality, 'self-service' and } \\
\text { nutrition. }\end{array}$ \\
\hline $\begin{array}{l}\text { Factors important for } \\
\text { the selection of fast food } \\
\text { restaurants: an empirical } \\
\text { study across three cities } \\
\text { of Pakistan. Usman } \\
\text { Ehsan (2012). }\end{array}$ & $\begin{array}{c}\text { In total } 447 \text { questionnaires were } \\
\text { randomly distributed among university } \\
\text { students of three cities. Data analysis } \\
\text { was done in SPSS Version } 17 . \\
\text { Important factors were identified by } \\
\text { factor analysis and ANOVA was used } \\
\text { to measure the differences (among } \\
\text { cities). }\end{array}$ & $\begin{array}{l}\text { The primary purpose of this } \\
\text { study is to explore the } \\
\text { factors that influence } \\
\text { selection of restaurants and } \\
\text { also to identify the cultural } \\
\text { or regional differences in } \\
\text { consumer behaviour } \\
\text { amongst students. }\end{array}$ & $\begin{array}{l}\text { According to the findings, } \\
\text { customers considered price, } \\
\text { variety of food, promotional } \\
\text { deals and timely service as } \\
\text { important factors for the selection } \\
\text { of fast food restaurants. }\end{array}$ \\
\hline
\end{tabular}

Source: Prepared by authors, according to Lee and Ulgado (1997); Kivela (1997); Goyal and Singh (2007); Dabrowska (2011) and Ehsan (2012) 
After summarizing the research of other scholars, it was decided to use a survey questionnaire with closed questions to avoid ambiguous answers. The collected answers were analyzed using SPSS software, which helped to quickly and efficiently process the large amount of data. The online survey was launched on the $2^{\text {nd }}$ April 2014 and closed on the $2^{\text {nd }}$ May 2014. By that time 131 respondents had fully completed it. The sample size of 131 was calculated by using the formula provided below:

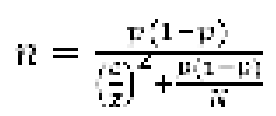

Source: Dikčius (2006). Marketingo tyrimai.Teorija ir praktika. Vilnius: VVAM, p.130

Variables in the formula stand for:

$\mathrm{n}$ - sample size

$\mathrm{N}$ - population size. According to Statistics of Lithuania there are 1174687 people aged from 15 to 44 who are considered as a targeted market for fast food restaurants.

$\mathrm{p}-0.5$, as the proportion of population is not known.

$\mathrm{e}-$ margin of error $8.5 \%$.

$\mathrm{z}-\mathrm{z}$-score is 1,96 with $95 \%$ level of confidence.

The questionnaire contained three groups of questions: behavioral, scale and demographic questions. Firstly, respondents were asked to answer 5 behavioral questions in order to examine the restaurant visitors' behavior. These questions included: the frequency of visiting a restaurant; amount of money spent there; time of a day when usually a restaurant was visited; restaurants visited most frequently and restaurants visited during last three months. Later on the distribution of results was analyzed according to the age and income categories. The $1^{\text {st }}$ and $2^{\text {nd }}$ questions were composed using the ordinal scale and the $3^{\text {rd }}, 4^{\text {th }}$ and $5^{\text {th }}-$ nominal scale. Secondly, the 7 scale questions were provided to respondents to understand their opinion towards innovation. All these questions were designed using the Stapel scale, where respondents had to evaluate the importance of criteria while selecting a restaurant (when 1 was not important, 10 - very important). The $6^{\text {th }}$ question asked to evaluate the extent of the importance of innovation in fast food restaurants in general. For $7^{\text {th }}, 8^{\text {th }}, 9^{\text {th }}, 10^{\text {th }}$ and $11^{\text {th }}$ questions 31 variables were selected representing customer selection criteria of fast food restaurants that could be divided into 5 distinctive groups:

1) Food characteristics: selection variety of meals, taste, presentation, variety of beverages, type (country specialty), healthiness (nutrition), quality of food, quantity of food.

2) Service aspects: speed of service, food serving style, kindness of staff, free extras, professionalism of staff, ordering ease, drive through possibility, home delivery.

3) Location: distance from work, distance from home, distance from entertainment, distance from entertainment, distance from shopping center, uniqueness of the location.

4) Physical characteristics: comfort of the interior, availability of free spaces, modernity of restaurant, cleanliness.

5) Additional features: entertainment, hours of operation, discounts, music, overall image and reputation, internet connection.

$12^{\text {th }}$ question asked people to evaluate the importance of innovation among variable groups in previously mentioned questions. Finally, 5 demographic questions were used in order to find out demographical division regarding gender, age, level of education, marital status and income. The $13^{\text {th }}, 15^{\text {th }}$ and $16^{\text {th }}$ were made using nominal scale, while $14^{\text {th }}$ and $17^{\text {th }}$ - ordinal. Out of 131 respondents $53.4 \%(n=70)$ were female and $46.6 \%$ were men $(n=61)$. The majority of people who responded were aged from 18 to 25 , making $74.8 \%$ ( $n=98)$ of total respondents. Another $15.3 \%(\mathrm{n}=20)$ belonged to the age group 26-35 and 9.9\% were in other age groups. None of respondents were younger than 18 and older than 60 years old. The research showed that $52.7 \%(\mathrm{n}=69)$ of respondents were undergraduate students at university, 31.3\% $(\mathrm{n}=41)$ had already finished it, 9.2\% $(\mathrm{n}=12)$ were students at college and 6.9\% ( $\mathrm{n}=9)$ - at high school. Out of 131 respondents $64.1 \%(\mathrm{n}=84)$ were single. Other groups of respondents were living in unregistered customary marriage, were married, divorced or widowed 
respectively taking $16.8 \%(n=22), 15.3 \%(n=20), 3.1 \%(n=4)$ and $0.8 \%(n=1)$. The distribution of the sample, based on net income showed that the majority of respondents $-37.4 \%(\mathrm{n}=49)$ earned from $1001 \mathrm{Lt}$ to $2000 \mathrm{Lt}$. $29 \%(n=38)$ received up to $1000 \mathrm{Lt}, 19.8 \%(n=26)$ from $2001 \mathrm{Lt}$ to $4000 \mathrm{Lt}$, and $13.7 \%(\mathrm{n}=18)$ more than 4000 Lt. Finally, the typical respondent of this research was either male or female single student with income from up to $2000 \mathrm{Lt}$ per month.

\section{Fast food restaurant selection criteria and its role on innovation}

The quantitative research provided important results on respondents' behaviour in the fast food market. It showed that $48.9 \%(n=64)$ visit a restaurant once a week, other $23.7 \%(n=31)-$ more than once a week. As a result, the tendency of weekly visiting habit can be noticed among almost a half of respondents. Also, Kendall's tau-b test revealed that a positive correlation exists between the frequency of visiting a restaurant and age groups, with the value of 0.224 . Since the value falls into interval $0.2-0.4$, correlation is considered to be weak. The significance of correlation is tested by using Approx. Sig. parameter, which in this case shows significance level of 0.002 (less than 0.05 - significance level of quantitative research). Consequently, it is assumed that people within higher age group chooses fast food restaurant less frequently than youngsters.

The majority of respondents, $64.9 \%(\mathrm{n}=85)$, stated that they usually spend from $10 \mathrm{Lt}$ to $20 \mathrm{Lt}$ in a restaurant, while other $16.8 \%(n=22)$ - less than $10 \mathrm{Lt}$ and $18.4 \%(\mathrm{n}=24)$ more than $20 \mathrm{Lt}$. The age and income are important factors affecting the amount spent in a fast food restaurant, because Kendall's tau-b measurement showed a weak positive correlation between amount of money spent and age (approx. sig. $=0.002$, value $=$ 0,305 ), and income (approx. sig. $=0.00$, value $=0.301$ ). It is assumed that people within higher age and income groups tend to spend more money in a fast food restaurant. According to the analysed data, it is noticed that more than a half of people choose dining in the evening, making $54.2 \%(n=71)$ of total respondents. Others visit a restaurant similarly either in the afternoon or at night $-24.4 \%(\mathrm{n}=32)$ and $21.37 \%(\mathrm{n}=28)$ respectively.

Further, respondents were asked to choose few restaurants they visit most frequently. The analysis revealed that the most popular fast food restaurant in Lithuania is McDonald's - 109 respondents visited McDonald's frequently. The second place was shared by Hesburger and Pizza Express, scoring 56 respondents each. Sushi Express followed with 46 respondents. It is also necessary to mention that 11 respondents indicated other fast food outlets not presented in the questionnaire as most frequently visited ones. Those are: Chief Pizza, Pizza Max, Burger King, Subway, Statoil, CanCan and Domino. Results are visible in Figure 4.

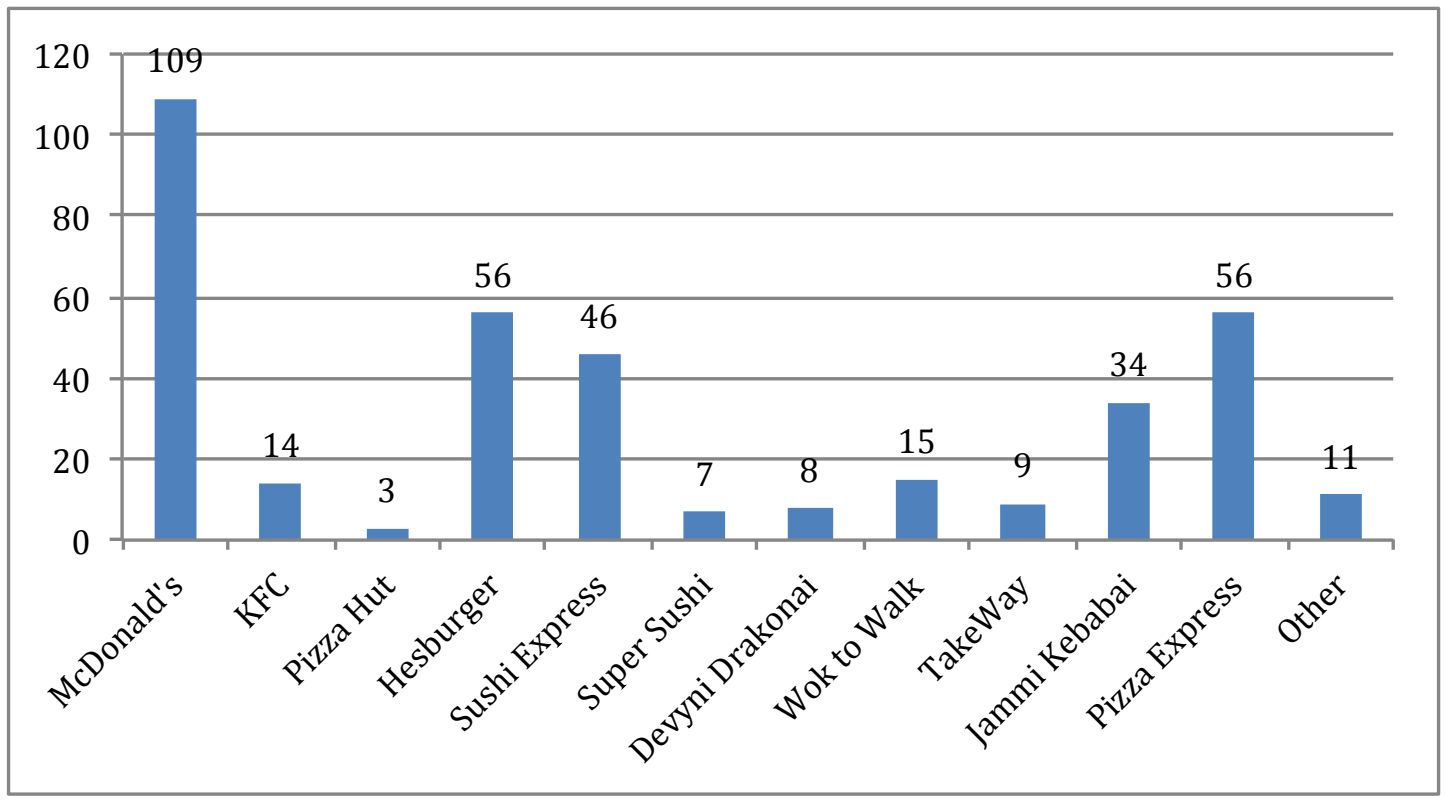

Fig. 4. Most frequently visited restaurants, by numbers of answers Source: prepared by authors 
Furthermore, respondents were asked to evaluate the importance of innovation from 1 to 10 while selecting a fast food restaurant. As a result, according to the mean, the overall importance reads 7.64 out of 10 . It can be assumed that respondents tend to think that innovation is an important factor influencing their selection of fast food restaurant. However, it is crucial to outline that opinions among respondents differ considerably because the standard deviation is high (2.065) and the values vary from 1 to 10 (see Table 7).

Table 7. Importance of innovation while selecting a fast food restaurant.

\begin{tabular}{|c|c|c|c|c|c|}
\hline & $\mathrm{N}$ & Minimum & Maximum & Mean & Std. Deviation \\
\hline Importance of innovation & 131 & 1 & 10 & 7,64 & 2,065 \\
Valid N (listwise) & 131 & & & & \\
\hline
\end{tabular}

Source: prepared by authors, according to survey results.

To continue, the analysis provided results upon the importance of particular selection criteria in five distinctive groups. An ingenious analysis was done to check the overall importance of innovation in these groups. First of all the quality of measurement was checked with Cronbach's $\alpha$ in order to find out if factors were reliable enough to use. Consequently, results showed that Cronbach's $\alpha$ of groups - 'service aspects', 'physical characteristics', 'additional features' and 'innovation in factor groups' were close to 0.8 which is considered as ideally acceptable condition. Factor groups 'food characteristics' and 'location' were close to 0.7 which is also an acceptable reliability coefficient, since lower thresholds are also used in the literature (Nunnally, 1978; Santos, 1999). Finally, it can be assumed that all the selection criteria used in the research are significantly reliable. Results are illustrated in the Table 8.

Table 8. Cronbach's Alpha

\begin{tabular}{|c|c|c|}
\hline & Cronbach's Alpha & N of Items \\
\hline Food characteristics & 0,742 & 8 \\
Service aspects & 0,790 & 8 \\
Location & 0,731 & 5 \\
Physical characteristics & 0,770 & 4 \\
Additional features & 0,769 & 6 \\
Innovation in factor groups & 0,884 & 5 \\
\hline
\end{tabular}

Source: prepared by authors, according to survey results

Based on research results, respondents indicated taste as the most important restaurant selection criterion related to food ( $\mu=9.63)$. Respondents' opinions varied the least comparing to other factors, because the standard deviation was the lowest -0.91 . The quality of food $(\mu=9.21)$ and quantity of food $(\mu=8.15)$, as well as presentation $(\mu=8.48)$ were also selected as highly important factors with relatively lower standard deviations $1.29,1.65$ and 1.689 respectively. The complete results are shown in the Figure 5. 


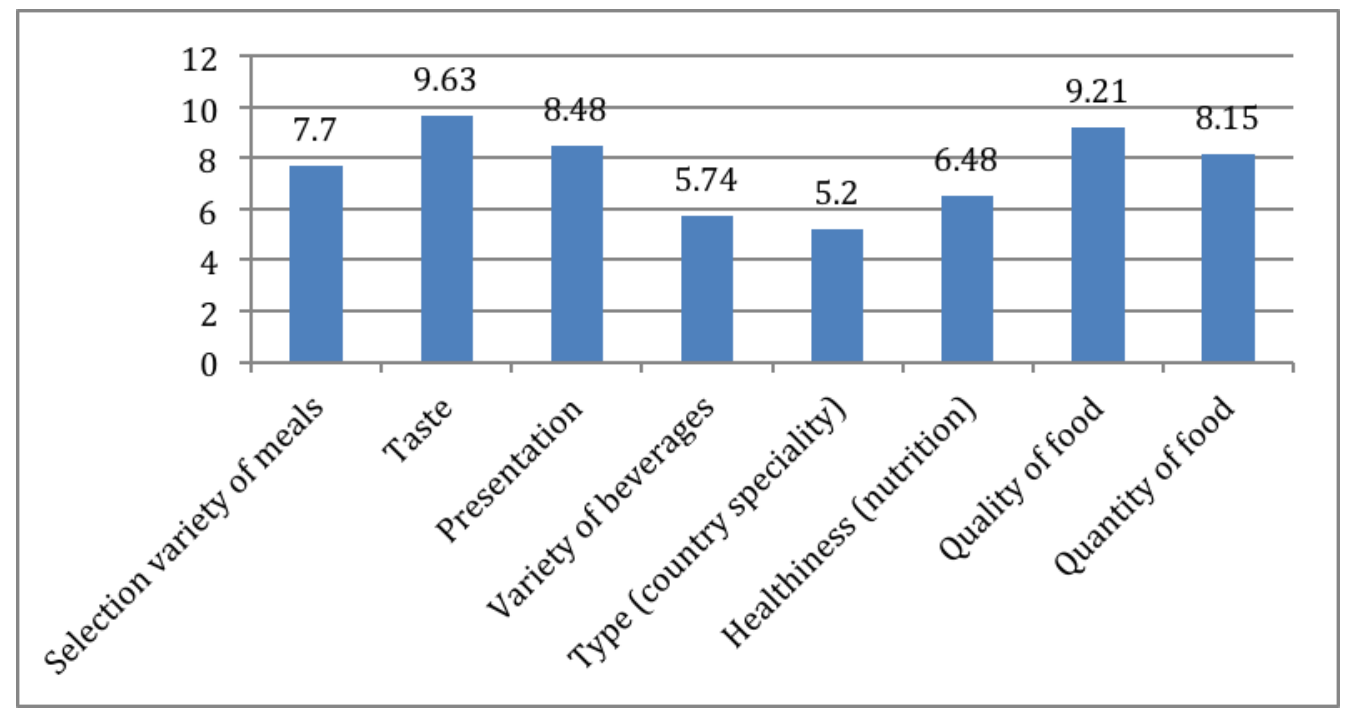

Fig. 5. Means of food characteristics

Source: prepared by authors, according to survey results

In addition, the Spearman's test was conducted in order to find out whether the correlation between particular factors and age and income groups existed. Negative significant correlation (sig. $(2$-tailed) $=0.035, \mathrm{r}=-0.184$ ) was identified between 'selection variety of meals' and income groups. It is considered to be a very weak correlation, since the value falls into interval $0-0.2$. A single star shows the error possibility which does not exceed 0.05 . Therefore, it can be assumed that people with higher income pay less attention to selection variety of meals. Although the majority of service aspects are considered to be of high importance while selecting a fast food restaurant, 'speed of service' can be distinguished as the most important one $(\mu=9.02)$ with a relatively lower standard deviation -1.55 . Respondents also selected 'kindness of staff' $(\mu=8.82)$, 'ordering ease' $(\mu=8.73)$ and 'food serving style' $(\mu=8.26)$ as very important factors. See results in the Figure 6.

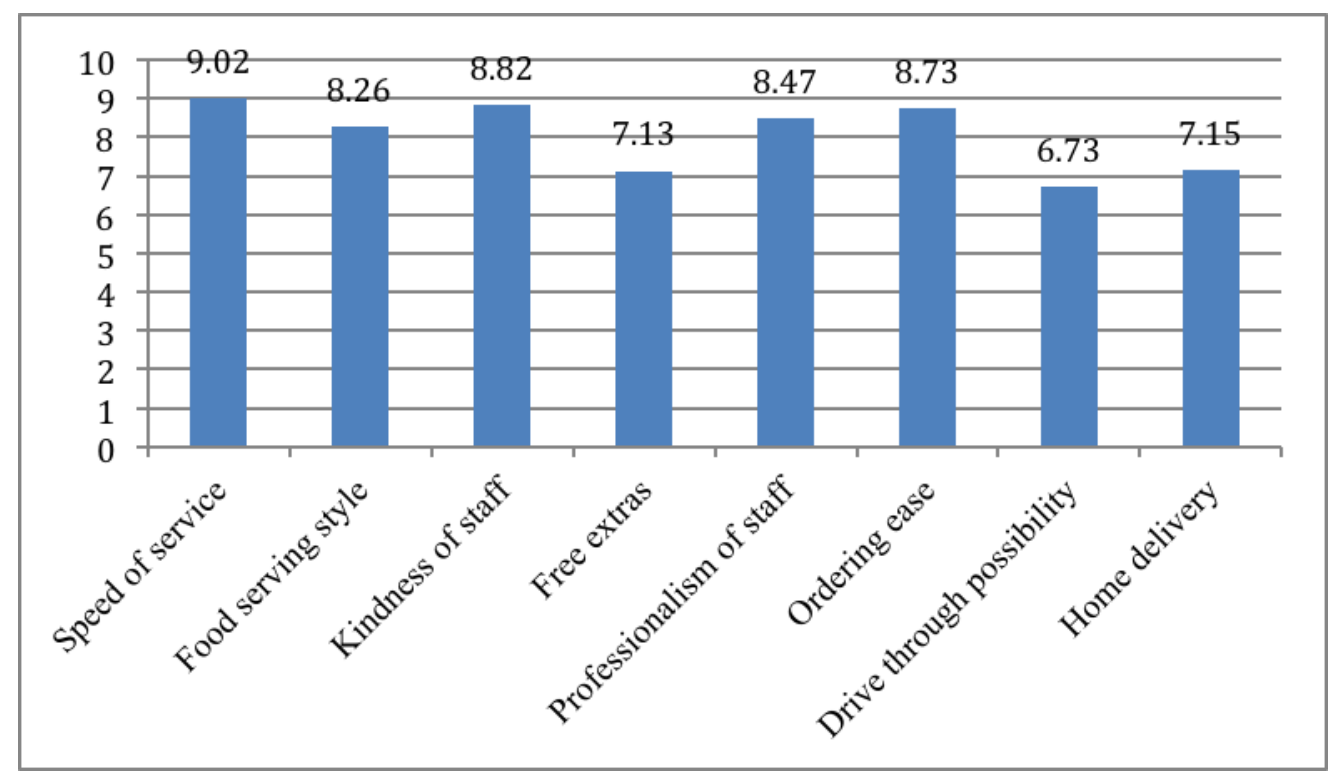

Fig. 6. Means of service aspects

Source: prepared by authors, according to survey results 


\section{Kindness of staff}

The analysis revealed that home delivery tends to be a more important selection criterion among younger people, since a weak negative correlation exists between the factor 'home delivery' and age groups (sig. (2-tailed) = $0.009, \mathrm{r}=-0.228$ ). A double star indicates that $1 \%$ maximum error is allowed. Also, Spearman's test showed a very weak negative correlation between 'free extras' and income groups (sig. (2-tailed) $=0.025, \mathrm{r}=-0.196$ ). Thus, it can be assumed that people who earn less prefer free extras offered by a restaurant more. Even though opinion of respondents deviates considerably, 'distance from home' $(\mu=7.63)$ and 'distance from entertainment' can be distinguished as the most important selection factors of a restaurant. This means people prefer restaurants that are closer to their home and various entertainment venues. The latter is negatively correlated with age (sig. (2-tailed) $=0, r=-0.317$ ) and income groups (sig. (2-tailed) $=0.001, r=-0.283$ ). It can be interpreted that younger people, who earn less, tend to look for restaurants around entertainment venues, due to a specific life style and transportation difficulties. Moreover, there is a very weak negative correlation identified between 'distance from shopping centre' and income groups (sig. (2-tailed) $=0.028, \mathrm{r}=-0.193$ ). It can be concluded that people with higher income are less concerned whether a fast food restaurant is in or around a shopping centre. Results are shown in Figure 7.

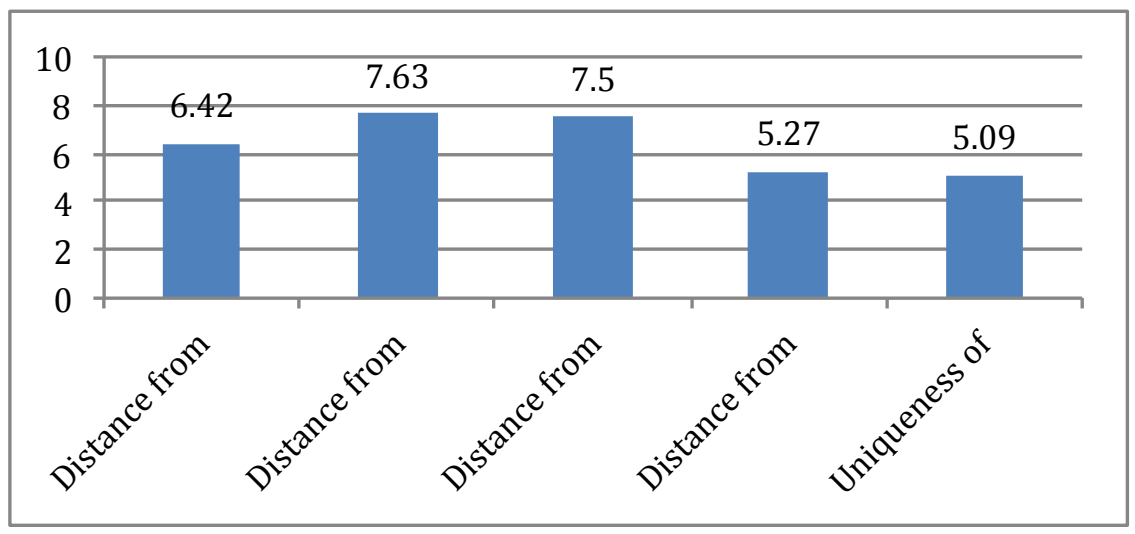

Fig. 7. Means of location criteria

Source: prepared by authors, according to survey results

The most important physical characteristics of a fast food restaurant identified by respondents are cleanliness $(\mu=9.5)$ and availability of free spaces $(\mu=8.47)$ with relatively lower standard deviations -0.898 and 1.619 respectively. See results in the Figure 8.

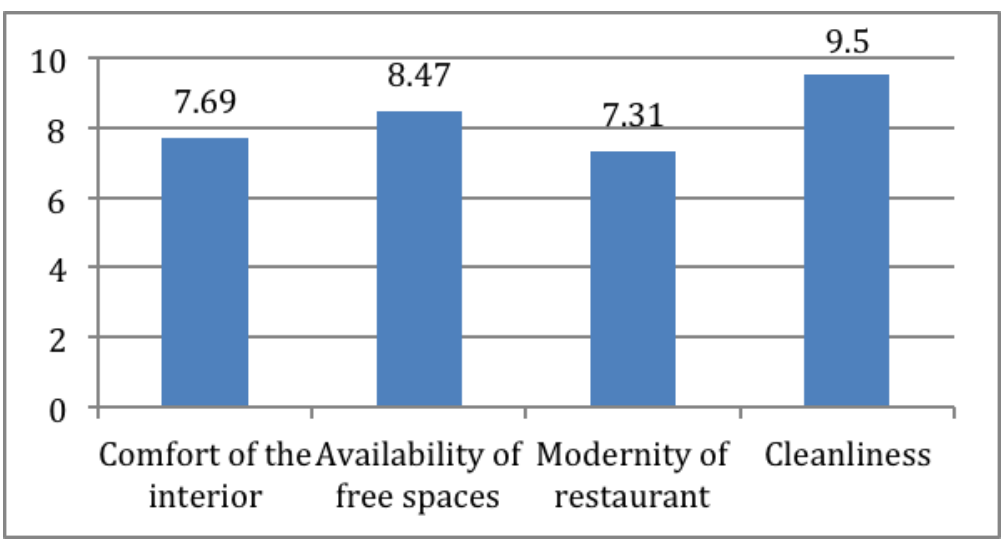

Fig. 8. Means of physical characteristics 
Furthermore, respondents also evaluated the importance of additional features for restaurant selection. As the most important factor was indicated 'hours of operation' $(\mu=8.87)$ with the lowest standard deviation -1.52 . Other criteria like 'discounts' and 'overall image and reputation' also got high means - 8.24 and 7.79 respectively. Results are visible in the Figure 9. Moreover, the analysis revealed that a weak negative correlation exists between age groups and 'discounts' (sig. (2-tailed) $=0, \mathrm{r}=-0.348)$, 'internet connection' (sig. (2-tailed) = $0.013, \mathrm{r}=-0.217$ ), music ( $\mathrm{sig}$. (2-tailed) $=0, \mathrm{r}=-0.305$ ) and a very weak negative correlation is noticed between age groups and 'hours of operation' (sig. (2-tailed) $=0.038, \mathrm{r}=-0.182)$. Conclusions can be drawn that older people tend to care less about hours of operation, availability of internet connection, discounts and music in a fast food restaurant. In addition, a weak negative correlation is detected between income groups and discounts (sig. $(2$-tailed $)=0, \mathrm{r}=-0.345)$. That means discounts are less important for people with higher income.

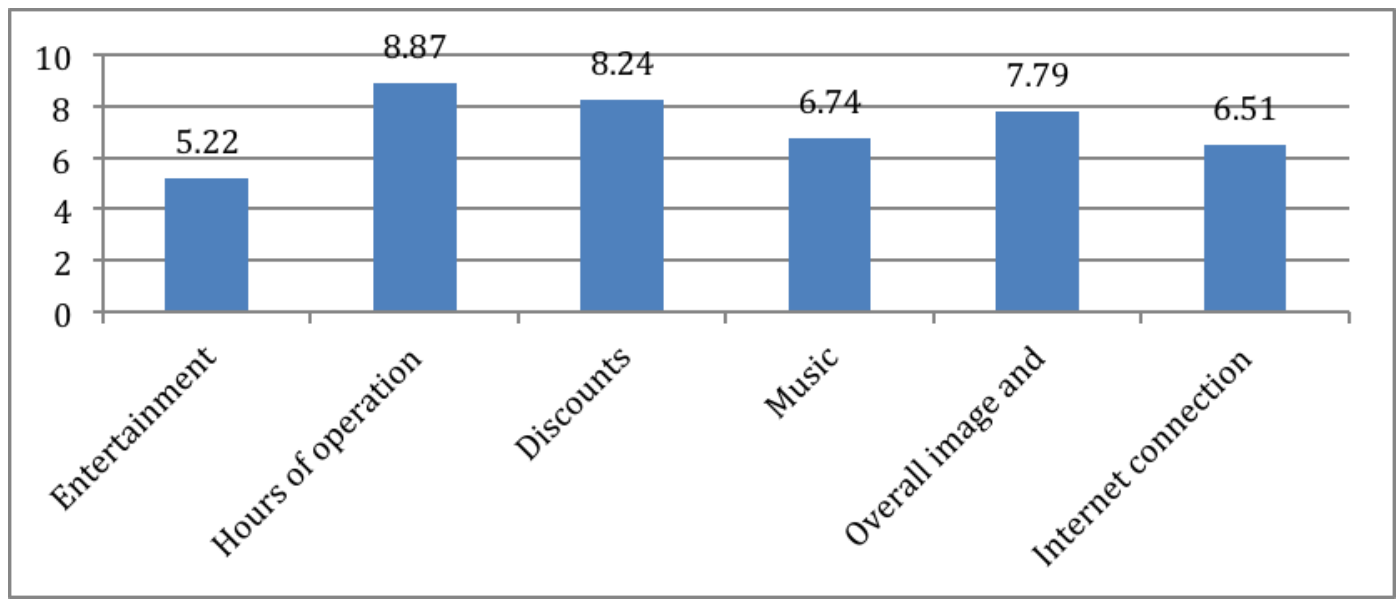

Fig. 9. Means of additional features

Source: prepared by authors, according to survey results

Finally, respondents were asked to evaluate the importance of innovation in particular criteria groups. Results revealed that the most innovation is needed in the areas related to food and service. They were marked by the highest means -8.2 and 8.18 respectively, although opinions varied considerably among respondents. Innovation for additional features of a fast food restaurant was evaluated to be the least important $(\mu=6.32)$. Location $(\mu=7.05)$ and physical characteristics $(\mu=7.04)$ were evaluated similarly important. It is also crucial to outline that such groups as 'service aspects', 'physical characteristics' and 'additional features' are negatively correlated with income groups. It was detected that a very weak correlation within groups 'physical characteristics' (sig. (2-tailed) $=0.032$, value $=-0.188$ ), and weak correlation within groups 'service aspects' (sig. $(2$-tailed $)=0$, value $=-0.302)$ and 'additional features' $($ sig. $(2$-tailed $)=0.005$, value $=-0.242)$ exists. As a result, the more income people receive, the less they are concerned with innovation in previously mentioned groups of restaurant selection criteria. Results are illustrated in Figure 10.

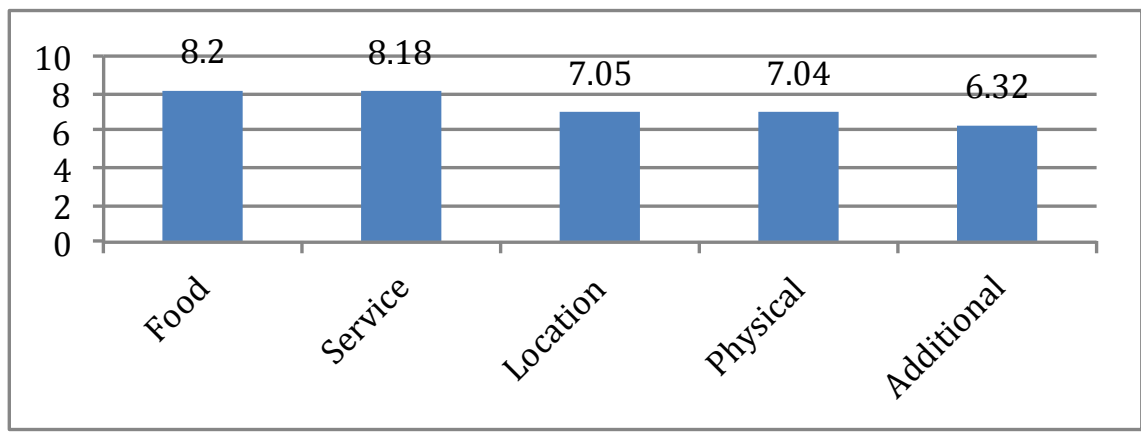

Fig. 10. Means of selection criteria groups; respondents' opinions

Source: prepared by authors, according to survey results 
It was also intended to carry out Independent-samples $\mathrm{T}$ Test analysis in order to find out whether the opinion about innovation importance in particular selection criteria groups differs by gender. In all cases, female generated higher means then male respondents, leading to the assumption that women more than men consider innovation to be important (see Figure 11). However, results showed that there was no significant difference between male and female opinions about innovation importance in particular fast food restaurant selection criteria groups, since Sig. (2-tailed) showed higher values than 0.05 .

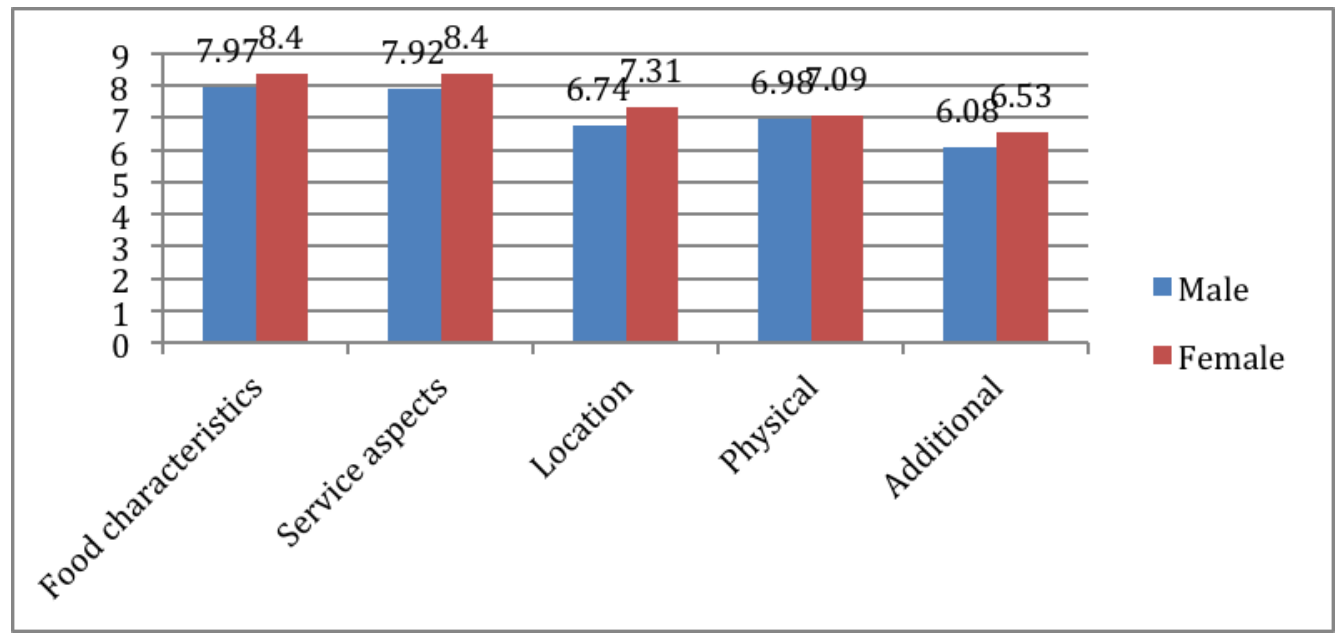

Fig. 11. Means of selection criteria groups by gender

Source: prepared by authors, according to survey results

Several conclusions can be drawn derived from the survey. Lithuanian fast food restaurants should be more innovative in their food and service development processes and should pay a sufficient attention to location and additional features of their restaurant in order to attract more customers and fulfil their needs. They need to improve their product and service commercialization processes and implement these innovations more often.

\section{Conclusions and recommendations}

The paper tackles the importance of innovation from the consumers' perspective. It also provides insights about consumer behaviour and selection criteria of fast food restaurants, which are beneficial for fast food restaurants in order to be successful, commercialize their innovations more efficiently and generate higher profits. The aim was to overview how consumers' age, income and gender influence certain fast food restaurant selection decisions and perception towards innovations in different categories.

The quantitative research revealed that the most important innovations to customers are in food characteristics, such as taste, food quality, food quantity, presentation and service aspects, such as speed of service, kindness of staff, the ease of ordering. It shows that Lithuanian consumers mostly care about things that they can see in their plate, which leads to a conclusion that companies should apply product innovations to improve the food quality. Furthermore, they need to develop their service and process innovations in order to provide their products in the most attractive way; to improve operational efficiency and ensure high standards with employee training, competency building and strategy creation. The analysis showed that the most important selection criteria are: cleanliness and available free spaces within the physical characteristics group, as well as hours of operation, discounts and overall images out of additional features group. Finally, the distance from home and entertainment spots are also selected as important factors for selection of a fast food restaurant.

Younger people tend to visit fast food restaurants more frequently than older. The amount spent is significantly lower within lower age and income groups. Thus, the tendency can be noticed that younger people with low income are the most frequent visitors of fast food outlets. Younger people are more attracted by service aspects of fast food restaurants like home delivery, and additional features, such as discounts, internet connection, music 
and hours of operation. People with lower income tend to spend less amount of money in a restaurant. Consequently, they are more concerned with free extras and provided discounts. Therefore, people within higher income group tend to care less about service, physical and additional features of a fast food restaurant. The conclusion can be drawn that the overall concern regarding innovations diminishes within higher income. It is worth mentioning that people who earn more state that distance of a restaurant from entertainment spots and shopping centres are less important.

A new fast food restaurant in Lithuania should target young people with lower income, and should focus its innovation commercialization process on this demographic segment. A restaurant should be located around entertainment spots; it should provide home delivery service and consider longer hours of operation, since these are important factors for younger people. Such place should also include features such as internet connection and music. As lower income people spend less, a restaurant should take into account the possibility of free extras and discounts. It is also necessary to outline that respondents think that cleanliness and availability should be of high concern for a new restaurant.

The Lithuanian fast food market is rapidly expanding and is a very perspective environment. However, to be successful in the Lithuanian fast food market, an entrepreneur has to be innovative, able to commercialize innovations and understand consumer behaviour. The present research is value-adding to both representatives of the fast food industry, who are interested in this particular region, and scientists due to the analysed liaison between the consumer behaviour and innovation processes.

\section{References}

Alam, I.; Perry, C. 2002. A customer oriented new service development process, Journal of services marketing 16(6): 515-534.

Baregheh, A., Rowley, J. Sambrook, S. Davies, D. 2011. Food sector SMEs and innovation types, British Food Journal 114(11): 16401653.

Barosso, J. M. 2013. Europe 2020 and open innovation in H2020. European Commision, Brussels. http://horizon2020projects.com/prknowledge-innovation-interviews/europe-2020-and-open-innovation-in-h2020. Viewed on May 7th.

Bigliardi, B. Dormio, A. I. 2009. An empirical investigation of innovation determinants in food machinery enterprises, European Journal of Innovation Management 12(2): 223-242.

Crossan, M. M. Apaydin, M. 2010. A Multi-Dimensional Framework of Organizational Innovation: A Systematic Review of the Literature, Journal of Management Studies 47(6): 1154-1191.

Dabrowska, A. 2011. Consumer behaviour in the market of catering services in selected countries of Central-Eastern Europe, British Food Journal 113 (1): 96-108.

Datta, A. 2011. An Integrative Model to Explain the Ability to Commercialize Innovations: Linking Networks, Absorptive Capacity, Ambidexterity and Environmental Factors, Journal of Management and Strategy. Vol. 2.

Datta, A. Reed, R. Jessup, L. 2013. Commercialization of innovations: an overarching framework and research agenda., American Journal of Business 28(2)

Dikčius, V. 2006. Marketingo tyrimai.Teorija ir praktika. [Marketing Research: Theory and Practice]Vilnius: VVAM, p.130

Drucker, P. F. 1998. The discipline of innovation. President and Fellows of Harvard College.

Drucker, P. F. 2002. Innovation and entrepreneurship. HarperCollins Publishers, Butterworth-Heinemann, 2007.

Ehsan, U. 2012. Factors important for the selection of fast food restaurants: an empirical study across three cities of Pakistan, British Food Journal 114(9): 1251-1264.

European Commision. 1997.. Oslo Manual. Organization for Economic Co-operation and Developent.

Europos Komisija. 2011. Nauja Inovaciju sajungos rezultatu suvestine. Pagrindiniai varžovai lenkia Europos Sajunga, nors daugelyje valstybių nariu padaryta pažanga. Briuselis. http://ec.europa.eu/enterprise/policies/innovation/facts-figures-analysis/index_en.htm 
Gia, K. P. 2011. Radical Innovation and Open Innovation: Creating New Growth Opportunities for Business. Hamburg: Diplomica Verlag GmbH.

Goyal, A.; Singh, N. P. 2007. Consumer perception about fast food in India: an exploratory study, British Food Journal 109(2): 182-195.

Hollanders, H. Sadki, N. S. 2014. Innovation Union Scoreboard. Maastricht Economic and Social Research Institute on Innovation and Technology, Netherlands.

Innovation policy in Lithuania. Mokslo, Inovacijų, Technologijų Agentūra. http://www.mita.lt/en/general-information/innovations/innovation-policy-in-lithuania. Viewed on May 7 th.

Jakūbavičius, A. Strazdas, R. Gečas, K. 2003. Inovacijos: procesai, valdymo modeliai, galimybès [Innovations: processes, management models, possibilities]. Lietuvos inovacijų centras, Vilnius.

Kivela, J. J. 1997. Restaurant marketing: selection and segmentation in Hong Kong, International Journal of Contemporary Hospitality Management 9(3): 116-123.

Lee, M.; Ulgado, F. M. 1997. Consumer evaluations of fast-food services: a cross-national comparison, The journal of services marketing 11(1): 39-52.

Lundvall, B. A. 2002. Innovation, growth, and social cohesion: the Danish model. Aalborg University, Paris.

Melnikas, B. Jakūbavičius, A. Strazdas, R. 2000. Inovaciju vadyba [Innovation management]. Technika, Vilnius.

Ottenbacher, M. C. Harrington, R. J. 2007. The innovation development process of Michelin-starred chefs, International Journal of Contemporary Hospitality Management 19(6): 444-460.

Ottenbacher, M. C. Harrington, R. J. 2008. The product innovation process of quick-service restaurant chains, International Journal of Contemporary Hospitality Management 21(5): 523-541.

Proposal for a Decision of the European Parliament and of the Council on the Strategic Innovation Agenda of the European Institute of Innovation and Technology (EIT): The Contribution of the EIT to a More Innovative Europe. European Parliament, Brussels, 2011.

Schumpeter, J. A. 1965. Capitalism, Socialism and Democracy. Unwin University Books.

Schumpeter, J. A. Clemence, R. V. 2009. Essays on Entrepreneurship, Innovations, Business Cycles and the Evolution of the Capitalism.

Trott, P. 2005. Innovation Management and New Product Development. 3rd ed. University of Portsmouth, Great Britain.

Von Stamm, B. 2008. Managing innovation, design and creativity. 2nd ed. Glasgow: Bell \& Bain.

Dr. Mindaugas LAUŽIKAS is a Professor at ISC Paris Business School (Institut supérieur du commerce de Paris), Doctor of Economic Sciences, Leader of Global Entrepreneurship Monitor (Lithuania). Lecturing experience in such countries as Georgia, Sweden, France, Spain, Malta, Moldova and Lithuania is supported by publications in the field of knowledge economy, entrepreneurship and innovation. Research interests: national systems of innovation, entrepreneurship, knowledge diffusion, innovation and human resource strategies.

Hailee TINDALE is a teacher/researcher at ISC Paris Business School and a doctoral student at the University of Bath School of Management working towards a DBA in Higher Education Management.

Lukas TRANAVIČIUS is a researcher in the fields of innovation and marketing, interested in service innovations and performance optimization among companies via the market research and financial analysis techniques. Currently successfully combines the career of a researcher and manager.

Emilis KIČIATOVAS is a researcher in the fields of innovations and the dynamics of small and medium enterprises, interested in innovative marketing instruments, innovation commercialization and entrepreneurship. Currently successfully combines the career of a researcher and manager.

This is an open access journal and all published articles are licensed under a

Creative Commons Attribution 4.0 International License

Copyright of Journal "Entrepreneurship and Sustainability Issues" ㄷ Entrepreneurship and Sustainability Center, All Rights Reserved 